\title{
Sketching Engineering Design in STEM Classroom: A Systematic Review
}

\author{
Siti Hajar Aisyah Zainuddin, Zanaton H. Iksan \\ Faculty of Education, Universiti Kebangsaan Malaysia, Bangi, Malaysia \\ Email: aisyah.bft5002@gmail.com,zanaton.iksan@ukm.edu.my
}

How to cite this paper: Zainuddin, S. H. A., \& Iksan, Z. H. (2019). Sketching Engineering Design in STEM Classroom: A Systematic Review. Creative Education, 10, 2775-2783.

https://doi.org/10.4236/ce.2019.1012204

Received: October 21, 2019

Accepted: November 25, 2019

Published: November 28, 2019

Copyright $\odot 2019$ by author(s) and Scientific Research Publishing Inc. This work is licensed under the Creative Commons Attribution International License (CC BY 4.0).

http://creativecommons.org/licenses/by/4.0/

(c) (i) Open Access

\begin{abstract}
Numerous studies in the last two decades have attempted to explain the significant relationship between effects of freehand sketching especially in the initial phase of idea generation in engineering design process approach. However, freehand sketches are not favoured by novice designer while generating design task. This paper aim to map how sketching skills benefit STEMenriched learning environment and enabling visually communicated ideas to craft novelty solutions. This systematic review analysed nine papers that use sketch as design tool in STEM enriched engineering design activities. The literature is retrieved from established online database such as SCOPUS and EBSCOHOST. Sketch significantly proves as powerful tool in prompting visual ideas, reflect prior knowledge, aid communication and collaborative practise and engage active learning. The infancy of research using matured student sample, different ethnic and social economic background will create interesting research opportunities in multiracial nation.
\end{abstract}

\section{Keywords}

Sketch, Engineering Design, Integrated STEM, Design, Systematic Literature Review

\section{Introduction}

Integration of science, technology, engineering and mathematics (STEM) in education is believed by educators and researchers worldwide as catalyst in empowering global economy. Hence, STEM-integrated approach has been in the limelight among practitioners in order to achieve the mission to produce qualified STEM professionals and inculcate STEM literacy to future global citizens (MOE, 2013). Educational researchers claimed the effectiveness of implementing STEM-integrated activities soars by generating competitive workforce equipped 
with 21st century skills (Husin et al., 2016), elevating students' interest (Mohd Shahali, Halim, Rasul, Osman, \& Mohamad Arsad, 2018); and improve cognitive domain. Problem-based, project-based or design-based learning were the typical instructional approach to carry out integrated STEM lesson in the classroom.

Recently, design-based learning has gained special attention among educators and researchers (Kelley \& Sung, 2017; King, English, King, \& English, 2016; English \& King, 2018). For example, United States put emphasized in teaching engineering design in K-12 STEM classroom, focusing on younger grades (Kelley \& Sung, 2017). In the recent education transformation, Malaysia introduced design and technology subject as new elective subject in national curriculum. Flexibility characteristics of design enable its application in various area of interest (Kelley \& Sung, 2017; Wendell et al., 2010) including engineering design (Dym, Agonino, Eris, Frey, \& Leifer, 2005). Growing body of literature supported the effectiveness of engineering design in elevating student interest in STEM subjects and sustain affection towards future STEM career (Mohd Shahali, Halim, Rasul, Osman, \& Mohamad Arsad, 2018; Tseng, Chang, Lou, \& Chen, 2013). Compared to conventional learning model, engineering design generates creativity by giving students chances to design novelty real-world solution (Bartholomew \& Strimel, 2018). Furthermore, students are more likely to involve in engineering design activities when compared to other components of the integrated discipline (Tseng, Chang, Lou, \& Chen, 2013).

\section{Engineering Design Learning in STEM}

Systematic literature review by (Strimel \& Grubbs, 2017) extensively map the P-16 United States curricula using different number of engineering design process models. Engineers design creative solutions to solve real-world problems (Goktepe Yildiz \& Ozdemir, 2018). Students are directed by the five-step process in engineering design in order to solve an open-ended design process. Students share positive outcome engaging actively engineering design challenges. Immersing students in engineering design processes and engineering practices creates meaningful and deepen core understanding (Guzey, Moore, Harwell, \& Moreno, 2016; Shahali, Halim, Rasul, Osman, \& Zulkifeli, 2017).

In engineering design activities, students, individual or collaboratively, produced authentic artefacts or solutions to accomplish design. A strong relationship between sketching and design has been reported in the literature (Hilton, Li, Newton, Alemdar, Pucha, \& Linsey, 2016). Thus, sketch and design are inter-related. Purpose of sketching rose from assisting the abstraction process, understand ill-defined problems and guide explorations of idea (Taborda, Chandrasegaran, Kisselburgh, Reid, \& Ramani, 2012). Creativity, ability to think critically, communicate and collaborate are the skills of successful future workforce of the $21^{\text {st }}$ century (Strimel \& Grubbs, 2017). Creative citizens are coined as national asset as the production of creative artefacts and driving innovation fos- 
ter economic growth of the nation. Hence, cultivating students design abilities can be highly beneficial for STEM learning concepts and develop higher order thinking. (Grubbs, Strimel, \& Kim, 2018) pointed out the importance of method of teaching and scaffolding techniques by teachers by identifying student design strategies, cognitive effort and ability to apply STEM concepts to achieve meaningful learning.

In Malaysian context, Bitara STEM programmed implement engineering design process in its activities to inculcate towards interest on STEM and STEM careers (Edy Hafizan, Lilia, Faszly, Kamisah, Zanaton, \& Sattar, 2015). The informal learning provides opportunities to students by experiencing "real-life" engineer roles and creatively solve real-world problems. Additionally, students who involve in engineering project learn how to solve problems, initiate creative thinking, acquire communication skills and able to work collaboratively (Guzey, Moore, Harwell, \& Moreno, 2016).

\section{Freehand Sketching in Engineering-Design Learning}

Freehand sketch is the simplest and fastest technique to visualize the idea by using the simplest tool yet efficient-paper and pencil. Besides, sketch adds value by acting as communication tool in delivering designer's big idea. Numerous studies in the last two decades have attempted to explain the relationship between positive effects of freehand sketching and its impact in engineering education especially in the initial phase of idea generation process. However, freehand sketches are not favoured by current engineering student while generating design task (Schmidt, Hernandez, \& Ruocco, 2012). Development of digital source such as CAD software in the engineering curricular prompted the neglect of sketching among novice designer (Hilton, Paige, Williford, Li, Hammond, \& Linsey, 2017; Uziak \& Fang, 2018). The result agreed with the findings of other studies, in which prove to become a challenge in promoting the use of sketching as routine practise and design thinking among novice designers (Hilton, Paige, Williford, Li, Hammond, \& Linsey, 2017; Hammond, Hilton, Linsey, Gamble, \& Li, 2018; Sung, Kelley, \& Han, 2019).

Several studies investigating freehand sketching have been carried out on its ability to improve spatial visualization skills. Quasi-experimental outcome from (Srinivasan, Smith, \& Bairaktarova, 2016) demonstrated how using freehand sketching as routine practise improve spatial visualization competencies in a supportive learning environment. Additionally, no significance difference between male and female student in sketching performance, enabling technical sketching skill to learn across gender and age if given appropriate instruction. However, it is no doubt that those with higher spatial visualization skills will perform better in engineering sketching activities. The findings should make an important contribution to the field of STEM learning as spatial skills is important in STEM and has potential in influencing one to pursue STEM career (Uttal \& Cohen, 2012). Therefore, in this paper, the author aims to map the prior works on how sketching is applied in engineering design activities. 


\section{Methodology}

The construction of systematic literature review is based on Preferred Reporting Items for Systematic Reviews and Meta-Analyses (PRISMA) which involves four phases: 1) identification, 2) screening, 3) eligibility and 4) inclusion. Well-known online research databases which are related to education, engineering and technology were selected to locate relevant literature sources using combination of keywords. The search key string used to retrieve literature are as in Figure 1. The last search is conducted on 18 June 2019. The search produces 31 articles. After inclusion and exclusion criteria, only 13 remains. After that, the abstract of each article was read to further eliminate articles that did not match the specific criteria of inclusion set. Nine articles remain as final.

\section{Result and Discussion}

Table 1 visually indicates the void of research within past efforts, thus paving way for future research undertakings. The growing literature body of integrated STEM, engineering design and sketch as design tool produced significant discovery in implementation of engineering design in the classroom.

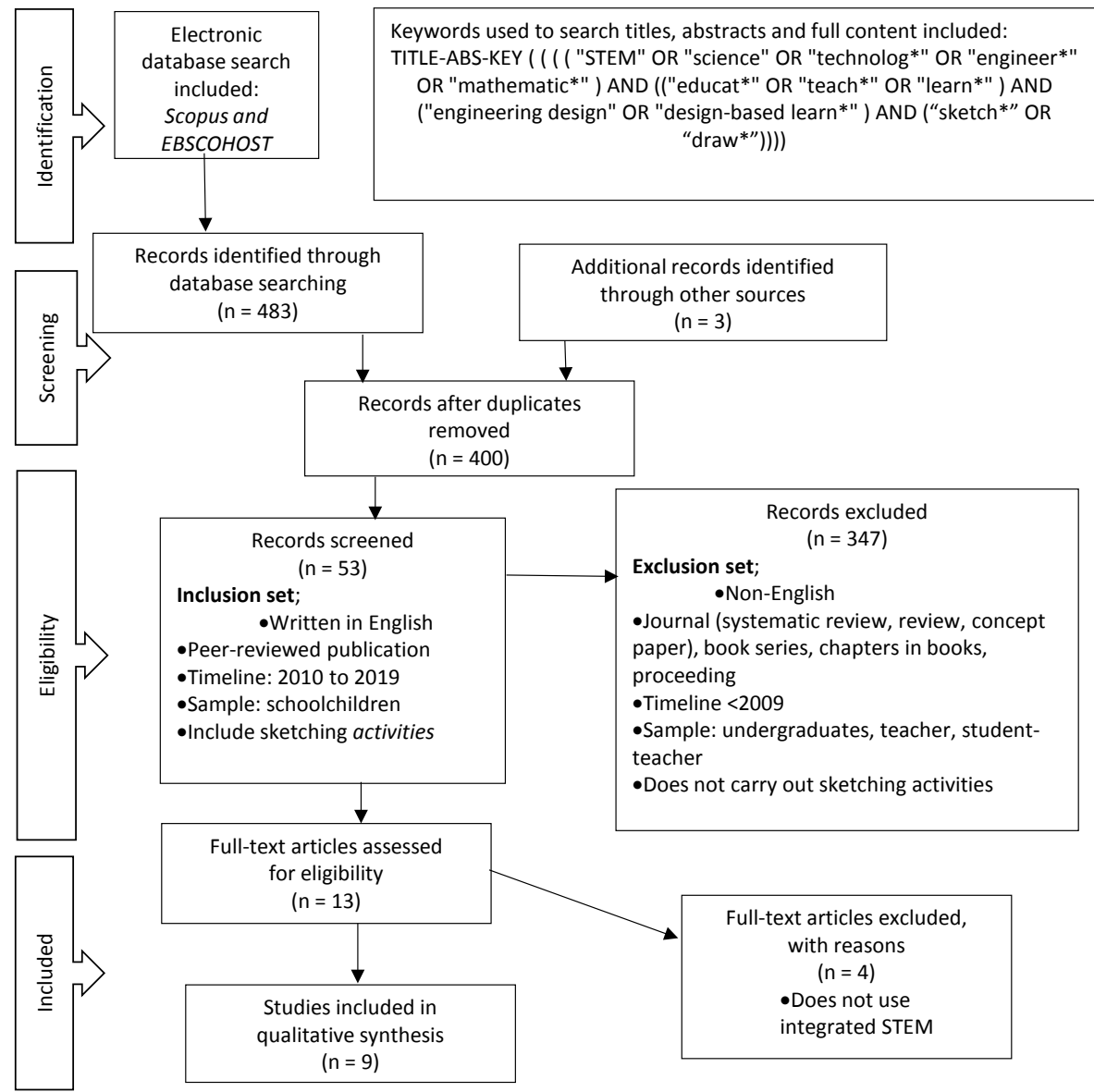

Figure 1. A flow diagram detailing the application of PRISMA to the qualitative synthesis of relevant literature of sketching in STEM research conducted between January 2010 and June 2019. 
Table 1 shows the high opportunities of studies which combine STEM, engineering design and sketch as design tool in stimulating creativity. From nine studies listed, only five incorporate sketches in their research design. This prove sketching in engineering design, in the context of integrating STEM teaching and learning is still in infancy. Sketching is perceived as "traditional technology" in the emergence of high-end digital gadgets pro to designing, nevertheless serve wide potential in engineering design education research. Previous research has indicated sketching possess positive impact on initial stage generation of idea in solving open-ended problems visually (King, English, King, \& English, 2016), producing innovation by creating authentic products (Kelley \& Sung, 2017) or simply act as communication support (Taborda, Chandrasegaran, Kisselburgh, Reid, \& Ramani, 2012). Currently, the focus of research involving sketching is to gain understanding how student use sketching to learn and how the process integrate and support science learning (Kelley \& Sung, 2017). focusing on middle schoolchildren as the "gate barrier" in early STEM attainment (Shahali, Halim, Rasul, Osman, \& Zulkifeli, 2017).

Three search results by (English, 2018) is actually part of longitudinal research in inculcating engineering design process thinking among elementary schoolchildren. This due to (Booth, Bhasin, \& Ramani, 2014) that sketching are skills that require time to develop. All five studies agreed that teacher's instruction play major role in supporting younger children ability to produce design in engineering-based project. In terms of research framework, (Kelley \& Sung, 2017)

Table 1. Overview of research paper based on search result, subject and methodology.

\begin{tabular}{|c|c|c|c|c|c|c|c|c|c|c|c|}
\hline \multirow[b]{3}{*}{ Author } & \multicolumn{11}{|c|}{ Results } \\
\hline & \multicolumn{4}{|c|}{ Search Subject } & \multicolumn{4}{|c|}{ Sample } & \multicolumn{3}{|c|}{ Methodology } \\
\hline & 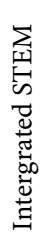 & 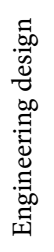 & 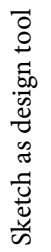 & 壳 & 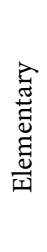 & $\underset{\vec{z}}{\stackrel{\theta}{z}}$ & 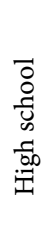 & 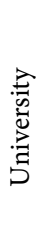 & 苛 & & 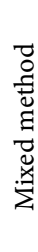 \\
\hline Sung, Kelly, \& Han (2019) & * & * & * & * & * & & & & & & * \\
\hline $\begin{array}{l}\text { Mohd Shahali, Halim, Rasul, Osman, \& } \\
\text { Mohamad Arsad (2018) }\end{array}$ & * & * & & & & * & & & & & * \\
\hline English \& King (2018) & * & * & * & & * & & & & & & * \\
\hline Estapa \& Tank (2017) & * & * & & & & & & * & & * & \\
\hline English, King, \& Smeed (2017) & * & * & * & & * & & & & & * & \\
\hline $\begin{array}{l}\text { Shahali, Halim, Rasul, Osman, \& Zulkifeli } \\
\text { (2017) }\end{array}$ & * & * & & & & * & & & * & & \\
\hline Zhou, Pereira, \& George (2017) & & * & * & & & * & & & & & * \\
\hline Kelley \& Sung (2016) & * & * & * & & * & & & & & * & \\
\hline English \& King (2015) & * & * & * & & * & & & & & * & \\
\hline
\end{tabular}


applied the works from (Hope, 2008) which identify cognitive levels by classification of student drawing designs while, (King, English, King, \& English, 2016) use the approach by (Crismond \& Adams, 2012).

The successful of integrating design sketch depend on instructional methods by practitioners. (Kelley \& Sung, 2017) proposed that young children need to be rationalized on sketch uses in completing their design task; creating meaningful learning. Sketches should be valued by the content of its ideas instead of the end product. Integrating design activities means higher time consumption in teaching and learning. Thus, becomes inhibitor for teachers as preferred choice of STEM instructional strategies in the classroom. As solution, the urge in using modular approach should be considered. Online resource prepared as guideline to assist teachers in implementing modular approach in schools. This create potential pool of research in investigating social interaction (i.e. student-student; teacher-student; teacher-teacher) and knowledge interaction (i.e. subject-subject) occurrence.

Teachers should consider the inhibitor of design process among students. Incorporating visual art in sketch designing helps to improve the student's motivation and lower the cognitive load to avoid frustration. This will test the skill of communication among teachers as middle school learners tend to give up. This also include on how teachers motivate the learners to improve their sketches while not focusing the details of the sketches but to the content of the sketches itself.

Sketching in engineering design is part of alternative assessment in measuring conceptual understanding in science learning. Alas, teachers need to be trained to understand the role of sketching in design, as well as how to assess the product of design sketch. Further work needs to be done to establish the understanding and self-efficacy of teacher to carry out design assessment as it will influence the result of design instruction.

\section{Conclusion}

This review analyses nine literatures which study include the use of sketch as process in engineering design in integrated STEM learning environment. Qualitative and mixed method is chosen as research design in all the study to record student's cognitive and affective response towards learning design. Sketch has been proven as powerful tool in prompting students to give ideas visually, investigate prior knowledge and aid communication and collaborative practise, engaging active learning. The infancy of research uses matured student sample, different ethnic and social economic background creating interesting research opportunities in multiracial nation.

\section{Acknowledgements}

The author wishes to thank the Faculty of Education, Universiti Kebangsaan Malaysia for supporting the educational research code PP-FPEND-2019; and 
Teacher Scholarship Programme at the Ministry of Education, Malaysia for providing the funding for her studies in Universiti Kebangsaan Malaysia.

\section{Conflicts of Interest}

The authors declare no conflicts of interest regarding the publication of this paper.

\section{References}

Bartholomew, S. R., \& Strimel, G. J. (2018). Factors Influencing Student Success on Open-Ended Design Problems. International Journal of Technology and Design Education, 28, 753-770. https://doi.org/10.1007/s10798-017-9415-2

Booth, J. W., Bhasin, A. K., \& Ramani, K. (2014). Art Meets Engineering Design: An Approach for Reducing Sketch Inhibition in Engineers during the Design Process. In ASME 2014 International Design Engineering Technical Conferences \& Computers and Information in Engineering Conference (pp. 1-12). Buffalo. https://doi.org/10.1115/DETC2014-35278

Crismond, D., \& Adams, R. S. (2012). A Scholarship of Integration: The Matrix of Informed Design. Journal of Engineering Education, 101, 738-797. https://doi.org/10.1002/j.2168-9830.2012.tb01127.x

Dym, C. L., Agonino, A. M., Eris, O., Frey, D. D., \& Leifer, L. J. (2005). Engineering Design Thinking, Teaching, and Learning. Journal of Engineering Education, 94, 103-120. https://doi.org/10.1002/j.2168-9830.2005.tb00832.x

Edy Hafizan, M. S., Lilia, H., Faszly, R., Kamisah, O., Zanaton, I., \& Sattar, R. (2015). Bitara-Stem Training of Trainers' Programme: Impact on Trainers' Knowledge, Beliefs, Attitudes and Efficacy towards Integrated Stem Teaching. Journal of Baltic Science Education, 14, 85-96.

English, L. D. (2018). Learning While Designing in a Fourth-Grade Integrated STEM Problem. International Journal of Technology and Design Education, 1-22. https://doi.org/10.1007/s10798-018-9482-Z

English, L. D., \& King, D. (2018). STEM Integration in Sixth Grade: Desligning and Constructing Paper Bridges. International Journal of Science and Mathematics Education, 17, 863-884. https://doi.org/10.1007/s10763-018-9912-0

Goktepe Yildiz, S., \& Ozdemir, A. S. (2018). The Effects of Engineering Design Processes on Spatial Abilities of Middle School Students. International Journal of Technology and Design Education, 1-22. https://doi.org/10.1007/s10798-018-9491-y

Grubbs, M. E., Strimel, G. J., \& Kim, E. (2018). Examining Design Cognition Coding Schemes for P-12 Engineering/Technology Education. International Journal of Technology and Design Education, 28, 1-22. https://doi.org/10.1007/s10798-017-9427-y

Guzey, S. S., Moore, T. J., Harwell, M., \& Moreno, M. (2016). STEM Integration in Middle School Life Science: Student Learning and Attitudes. Journal of Science Education and Technology, 25, 550-560. https://doi.org/10.1007/s10956-016-9612-x

Hammond, T., Hilton, E. C., Linsey, J. S., Gamble, T., \& Li, W. (2018). Back to Basics: Sketching, Not CAD, Is the Key to Improving Essential Engineering Design Skills. In International Design Engineering Technical Conferences and Computers and Information in Engineering Conference (V007T06A051). Quebec. https://doi.org/10.1115/DETC2018-86325

Hilton, E. C., Paige, M., Williford, B., Li, W., Hammond, T., \& Linsey, J. (2017). Improving the Sketching Ability of Engineering Design Students. In 21st International Confe- 
rence on Engineering Design (pp. 217-224). Vancouver.

Hilton, E., Li, W., Newton, S. H., Alemdar, M., Pucha, R., \& Linsey, J. (2016). The Development and Effects of Teaching Perspective Free-Hand Sketching in Engineering Design. In Proceedings of the ASME 2016 International Design Engineering Technical Conferences and Computers and Information in Engineering Conference IDETC/CIE 2016 (pp. 1-8). Charlotte.

Hope, G. (2008). Thinking and Learning through Drawing. Thousand Oaks, CA: SAGE Publication Ltd.

Husin, W. N. F. W. et al. (2016). Fostering Students' 21st Century Skills through Project Oriented Problem Based Learning (POPBL) in Integrated STEM Education Program. Asia-Pacific Forum on Science Learning and Teaching, 17, 1-19.

Kelley, T. R., \& Sung, E. (2017). Sketching by Design: Teaching Sketching to Young Learners. International Journal of Technology and Design Education, 27, 363-386. https://doi.org/10.1007/s10798-016-9354-3

King, D., English, L. D., King, D., \& English, L. D. (2016). Engineering Design in the Primary School: Applying Stem Concepts to Build an Optical Instrument Concepts to Build an Optical Instrument. International Journal of Science Education, 38, 27622794.

MOE (2013). Malaysia Education Blueprint 2013-2025.

Mohd Shahali, E. H., Halim, L., Rasul, M. S., Osman, K., \& Mohamad Arsad, N. (2018). Students' Interest towards STEM: A Longitudinal Study. Research in Science \& Technological Education, 37, 1-19. https://doi.org/10.1080/02635143.2018.1489789

Schmidt, L. C., Hernandez, N. V., \& Ruocco, A. L. (2012). Research on Encouraging Sketching in Engineering Design. Artificial Intelligence for Engineering Design, Analysis and Manufacturing, 26, 303-315. https://doi.org/10.1017/S0890060412000169

Shahali, E. H. M., Halim, L., Rasul, M. S., Osman, K., \& Zulkifeli, M. A. (2017). STEM Learning through Engineering Design: Impact on Middle Secondary Students' Interest towards STEM. Eurasia Journal of Mathematics, Science and Technology Education, 13, 1189-1211. https://doi.org/10.12973/eurasia.2017.00667a

Srinivasan, A., Smith, J. D., \& Bairaktarova, D. (2016). Identifying Freehand Sectional View Technical Drawing Activities in Engineering Design Graphics Course to Enhance Spatial Skills of Engineering Students. In International Design Engineering Technical Conferences and Computers and Information in Engineering Conference (Vol. 3, pp. 1-7). Charlotte. https://doi.org/10.1115/DETC2016-60079

Strimel, G., \& Grubbs, M. (2017). A Critical Examination of Engineering Design Processes and Procedures. In Proceedings of the 33rd Pupil's Attitude toward Technology Conference. Philadelphia: Millersville University.

Sung, E., Kelley, T. R., \& Han, J. (2019). Influence of Sketching Instruction on Elementary Students' Design Cognition: A Study of Three Sketching Approaches. Journal of Engineering Design, 30, 199-226.

Taborda, E., Chandrasegaran, S., Kisselburgh, L., Reid, T., \& Ramani, K. (2012). Enhancing Visual Thinking in a Toy Design Course Using Freehand Sketching. In Proceedings of ASME IDETC/CIE 2012 (p. 10). Chicago. https://doi.org/10.1115/DETC2012-71454

Tseng, K.-H., Chang, C.-C., Lou, S.-J., \& Chen, W.-P. (2013). Attitudes towards Science, Technology, Engineering and Mathematics (STEM) in a Project-Based Learning (PjBL) Environment. International Journal of Technology and Design Education, 23, 87-102. https://doi.org/10.1007/s10798-011-9160-x

Uttal, D. H., \& Cohen, C. A. (2012). Spatial Thinking and STEM Education: When, Why, and How (p. 57). Amsterdam: Elsevier Inc. 
https://doi.org/10.1016/B978-0-12-394293-7.00004-2

Uziak, J., \& Fang, N. (2018). Improving Students' Freehand Sketching Skills in Mechanical Engineering Curriculum. International Journal of Mechanical Engineering Education, 46, 274-286. https://doi.org/10.1177/0306419017744156

Wendell, K. et al. (2010). Incorporating Engineering Design into Elementary School Science Curricula. In ASEE Annual Conference and Exposition, Conference Proceedings. Louisville.

https://peer.asee.org/poster-incorporating-engineering-design-into-elementary-schoolscience-curricula 